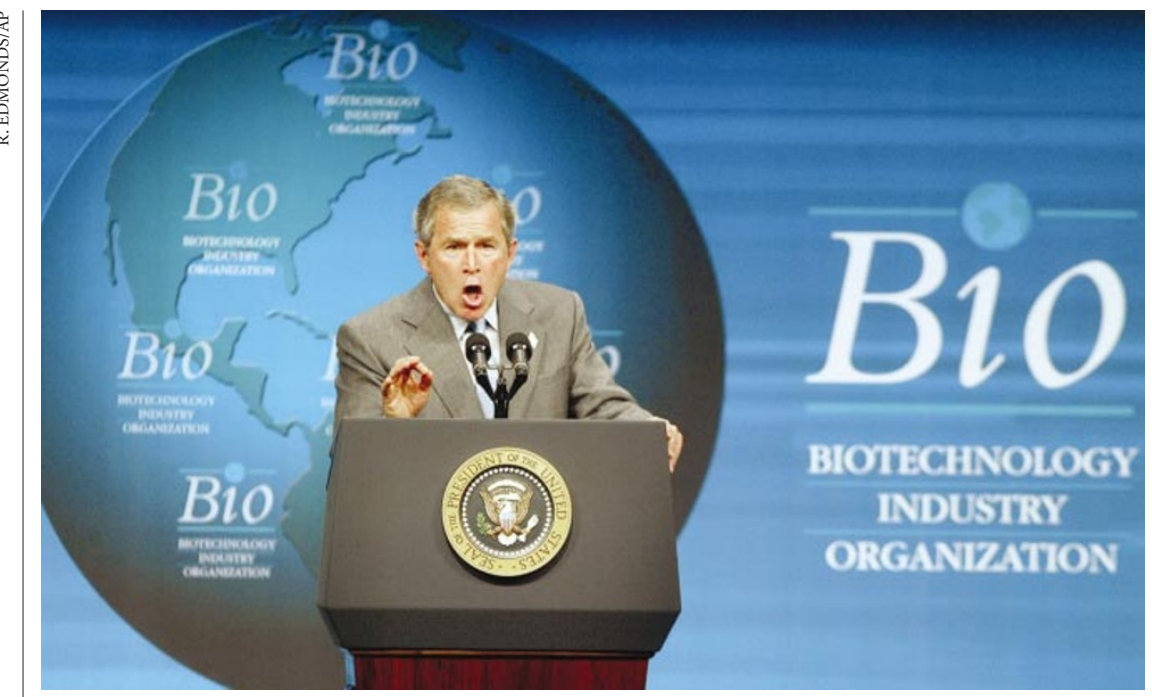

Opening the coffers: George Bush espouses further federal investment in biotechnology.

\title{
Share slump brings biotech firms to government's door
}

\section{Erika Check, Washington}

The biotechnology industry met this week in the seat of the US government - Washington DC - and the location couldn't have been more fitting. Because while entrepreneurs claim to shun government as a slow-moving dinosaur, observers say it is currently biotech's best friend.

The renewed interest in government money comes during a worldwide economic downturn. Analysts say that the funding desert has made smaller biotechnology companies - usually wary of the obligations that come with government financing - highly dependent on federal resources.

"Biotech companies are saying that they can't get start-up funding, so what can fill the void?" says Stephen Davis, an attorney with Heller, Ehrman, White and McAuliffe in New York. "The only thing that can do it is the federal government."

The Biotechnology Industry Organization (BIO) engaged in an unusually extensive public-outreach campaign for its annual meeting, with a barrage of advertising in Washington newspapers and television channels, and a two-day festival on the National Mall. Carl Feldbaum, president of the BIO, says that the organization has staged large campaigns at its past three conventions. "But here in Washington we've extended that theme exponentially," he says.

Several factors have forced biotech firms to turn to the government, analysts say. Stock markets around the world have slumped, leaving companies unable to raise money through initial public offerings. Last year, only four biotech firms in the United States went public — a tenfold drop since 2000. In Europe, only three biotechs went public last year.

Davis points out that early-stage biotech firms - those less than three years old, without a product ready to go to market - are having an especially hard time. Venturecapital funding for such firms totalled only $\$ 65$ million in the first quarter of this year a 70\% drop from the same period in 2002 . "Venture capitalists used to fund preclinical work, but now they want things in late phase II clinical trials with good data," Davis says.

This has made federal agencies such as the National Institutes of Health (NIH) more popular. The NIH is mandated to spend $2.5 \%$ of its extramural budget $-\$ 560$ million this year - on small-business awards.

In a speech to the BIO convention on 23 June, President George Bush backed even more federal investment in biotechnology. He called on Congress to pass a piece of legislation - Project BioShield — that would give $\$ 6$ billion over the next ten years for research and development to counter bioterrorism.

As always in Washington, the money is flowing both ways. Republican legislators, in particular, have benefited from large contributions from biotech companies in recent years. In return, critics say, the legislators have worked to weaken the Food and Drug Administration, which regulates the industry.

But analysts say that an increasingly cosy relationship with the government won't save the biotech industry's skin. They point out that \$6 billion over ten years isn't that much, next to what private sources used to invest. "Venturecapital firms measure cash flows in the billions of dollars," says Joe Cortright, a consultant based in Portland, Oregon. "The government just cannot invest on the same scale."

\section{Journals wrestle with definition of 'competing' interest}

Jonathan Knight, San Francisco

Scientific journals have been striving of late for greater openness about the competing financial interests of their contributors. But a spat over a paper in Science suggests that clashing views over what makes a conflict of interest means full transparency is hard to achieve.

Earlier this year, Australian activists noticed that a 2002 paper on the spread of herbicide resistance from transgenic canola to nearby fields (M. A. Rieger, M. Lamond, C. Preston, S. B. Powles and R. T. Roush Science 296, 2386-2388; 2002) did not mention that two biotechnology firms - Monsanto and Aventis Crop Sciences (now owned by Bayer) - paid nearly $20 \%$ of the costs of the trials.

Alerted to the fact by a reporter for an Australian television programme in early May, Science contacted the authors for an explanation. Science requires contributors to declare financial ties that might be construed as influencing the outcome of their research.

The authors responded that they did not view the company funding as a conflict of interest. Industry co-sponsors don't participate in the design or conduct of the study, nor are they permitted to vet the findings or stop publication, claims coauthor Christopher Preston, a molecular ecologist at the University of Adelaide. "I refuse to participate unless I can call the shots," Preston told Nature.

Although Science concluded that the funding did not amount to a conflict of interest, it has now revised its disclosure policy as a direct result of the incident, according to a statement provided to Nature on 23 June. Now, all funding sources must be revealed in the paper's reference section, Science says.

Many journals ask about conflicts of interest, but some authors don't realize that they have them, says Nicholas Cozzarelli, editor-in-chief of the Proceedings of the National Academy of Sciences. For instance, one contributor didn't feel that his position as chief scientist of a firm that was supporting his academic work needed to be mentioned as he didn't think the paper would affect the company's stock price, Cozzarelli says.

Nature has requested and published details of competing interests for every paper accepted since October 2001. Despite the rising number of researchers with ties to industry, of the 1,300 or so papers published under the policy, only 50 have declared competing interests. 